\title{
Molecular characterization and phylogenetic analyses of Lophodermella needle pathogens (Rhytismataceae) on Pinus species in the USA and Europe
} \author{
Stewart ${ }^{\text {Corresp. } 2}$ \\ ${ }^{1}$ Department of Forest Biological Sciences, University of the Philippines Los Baños, College, Laguna, Philippines \\ 2 Department of Agricultural Biology, Colorado State University, Fort Collins, Colorado, United States \\ 3 Forest Health Protection, Rocky Mountain Region, USDA Forest Service, Golden, Colorado, USA \\ 4 Forest Health Protection, Rocky Mountain Region, USDA Forest Service, Gunnison, Colorado, USA \\ 5 Northeastern Area State \& Private Forestry, USDA Forest Service, Durham, New Hamsphire, USA \\ ${ }^{6}$ Swiss Federal Institute for Forest, Snow and Landscape Research WSL, Birmensdorf, Switzerland \\ Corresponding Author: Jane E Stewart \\ Email address: Jane.Stewart@colostate.edu
}

Jessa Ata ${ }^{1,2}{ }^{2}$, Kelly S Burns ${ }^{3}$, Suzanne Marchetti ${ }^{4}$, Isabel Munck ${ }^{5}$, Ludwig Beenken ${ }^{6}$, James J. Worrall ${ }^{4}$, Jane E

Increasing prevalence of conifer needle pathogens globally have prompted further studies on pathogen identification and a better understanding of phylogenetic relationships among needle pathogens. Several Lophodermella species can be aggressive pathogens causing needle cast in natural pine forests in the USA and Europe. However, their relationships with other Rhytismataceae species have historically been based on similarities of only limited phenotypic characters. Currently, no molecular studies have been completed to elucidate their relationships with other Lophodermella needle pathogens. This study collected and sequenced three gene loci, namely: internal transcribed spacer, large ribosomal subunit, and translation elongation factor 1-alpha, from five Lophodermella needle pathogens from North America (L. arcuata, L. concolor, L. montivaga) and Europe (L. conjuncta and L. sulcigena) to distinguish phylogeny within Rhytismatacaeae, including Lophophacidium dooksii. Phylogenetic analyses of the three loci revealed that all but Lophodermella conjunctathat were sampled in this study consistently clustered in a wellsupported clade within Rhytismataceae. The multi-gene phylogeny also confirmed consistent nesting of $L$. dooksii, a needle pathogen of Pinus strobus, within the clade. Potential synapomorphic characters such as ascomata position and ascospore shape for the distinct clade were also explored. Further, a rhytismataceous species on $P$. flexilis that was morphologically identified as $L$. arcuata was found to be unique based on the sequences at the three loci. This study suggests a potential wider range of host species within the genus and the need for genetic characterization of other Lophodermella and Lophophacidium species to provide a higher phylogenetic resolution. 
1 Molecular characterization and phylogenetic analyses of Lophodermella needle pathogens 2 (Rhytismataceae) on Pinus species in the USA and Europe

3

4 5 6

7

Jessa P Ata ${ }^{1,2}$, Kelly S Burns ${ }^{3}$, Suzanne B Marchetti ${ }^{3}$, Isabel A Munck ${ }^{4}$, Ludwig Beenken ${ }^{5}$, James J Worrall ${ }^{3}$ and Jane E Stewart ${ }^{1}$

${ }^{1}$ Department of Agricultural Biology, Colorado State University, Fort Collins, CO 80523, USA

${ }^{2}$ Department of Forest Biological Sciences, University of the Philippines Los Baños, College, Laguna 4031, Philippines

${ }^{3}$ Forest Health Protection, Rocky Mountain Region, USDA Forest Service, Golden, CO 80401, USA

${ }^{4}$ Northeastern Area State \& Private Forestry, USDA Forest Service, Durham, NH 03824, USA

${ }^{5}$ Swiss Federal Institute for Forest, Snow and Landscape Research WSL, Zürcherstrasse 111, 8903 Birmensdorf, Switzerland

Corresponding Author:

Jane E Stewart ${ }^{1}$

Department of Agricultural Biology, Colorado State University, Fort Collins, CO 80523, USA

Email address: Jane.Stewart@colostate.edu

\section{Abstract}

Increasing prevalence of conifer needle pathogens globally have prompted further studies on identification and a better understanding of phylogenetic relationships among needle pathogens. Several Lophodermella species can be aggressive pathogens causing needle cast in natural pine forests in the USA and Europe. However, their relationships with other Rhytismataceae species have historically been based on similarities of only limited phenotypic characters. Currently, no molecular studies have been completed to elucidate their relationships with other Lophodermella needle pathogens. This study collected samples and sequenced three gene loci, namely: internal transcribed spacer, large ribosomal subunit, and translation elongation factor 1-alpha, from five Lophodermella needle pathogens from North America (L. arcuata, L. concolor, L. montivaga) and Europe (L. conjuncta and L. sulcigena) to distinguish phylogeny within Rhytismatacaeae, including Lophophacidium dooksii. Phylogenetic analyses revealed that all species except $L$. conjuncta were consistently clustered in a well-supported clade within Rhytismataceae. The multi-gene phylogeny also confirmed consistent nesting of $L$. dooksii, a needle pathogen of Pinus strobus, within the clade. Potential synapomorphic characters such as ascomata position and ascospore shape for the distinct clade were also explored. Furthermore, a rhytismataceous species on $P$. flexilis that was morphologically identified as $L$. arcuata was found to be 
38

39

40

41

42

43

44

45

46

47

48

49

50

51

52

53

54

55

56

57

58

59

60

61

62

63

64

65

66

67

68

genetically unique. This study suggests a potential wider range of pathogen species within

Lophodermella and the need for genetic characterization of other Lophodermella and

Lophophacidium species to provide a higher phylogenetic resolution.

\section{Introduction}

Conifer needle diseases are becoming increasingly prevalent due to several factors such as climate change and introduction to new hosts (Woods et al. 2005, Lee et al. 2017, Wyka et al. 2017, Brodde et al. 2018). Native needle pathogens emerge as they move into novel geographic areas while others are increasing in incidence due to faster sporulation enhanced by warmer and wetter conditions (Barnes et al. 2014, Gray et al. 2013, Rodas et al. 2016, Welsh et al. 2014). Recent examples of needle diseases with enhanced severity include Dothistroma needle blight (Woods 2014), Swiss needle cast and Cedar leaf blight (Gray et al. 2013), and white pine needle damage (Wyka et al. 2018, Broders et al. 2015).

In the western region of USA, an increasing prevalence of native Lophodermella needle pathogens, which may be attributed to climate change, were observed (Worrall et al. 2012) in Pinus contorta and $P$. flexilis. These two pine hosts are naturally dominant and ecologically important species along the Rocky Mountain Region (Lotan and Critchfield 1990, Schoettle 2004). Two needle cast epidemics caused by L. concolor and L. montivaga were recorded on $P$. contorta (Worrall et al. 2012) while increased frequency of $L$. arcuata infection was observed in patches of limber pine (P. flexilis) stands. Meanwhile, in Europe, heavy infection of L. sulcigena and L. conjuncta on European mountain pine (P. mugo) along the Swiss Alps were recorded in 2018 (Beenken 2019). Despite increasing incidence, there are no wide scale assessments on the impact of Lophodermella pathogens in natural pine stands amidst climate change. Past surveys reported short outbreaks or minor incidence of Lophodermella species such as L. cerina in southern USA, L. morbida in the western USA, L. maureri in Mexico, and L. orientalis in Asia (Czabator et al. 1971, Darker 1932, Minter 1988b, Minter 1993) but there are no recent surveys nor reports about their increasing incidence in these regions.

Thus far, only nine species belong to Lophodermella genus, including L. arcuata, L. cerina, L. concolor, L. maureri, L. montivaga and L. morbida in North America, L. conjuncta and L. 
69

70

71

72

73

74

75

76

77

78

79

80

81

82

83

84

85

86

87

88

89

90

91

92

93

94

95

96

97

98

99

sulcigena in Europe, and L. orientalis in Asia (Mycobank 2019). Lophodermella species (Rhytismataceae) are distinguished by their subhypodermal ascomata, clavate ascospores surrounded by mucilaginous sheath, and wider asci than the closely related genus Lophodermium (Darker 1967). While morphometric descriptions are clear in the literature, identification and differentiation among these Lophodermella species is challenging. This may be attributed to similarities in early symptoms of the disease, highly variable morphometric features at different developmental stages and mounting medium, secondary fungal invasion, and lack of ideally mature specimens (Worrall et al. 2012). Based on morphological characteristics there have been doubts on disease reports of $L$. sulcigena on $P$. radiata, $P$. halepensis and $P$. contorta while other diseases still need verification, such as the occurrence of L. montivaga on P. monticola and P. flexilis (Millar 1984).

Molecular characterization could help resolve classification of species closely related to Lophodermella such as the case of Lophophacidium dooksii on needles of five-needle Pinus strobus. In 1984, the newly described L. dooksii was classified under Phacidiaceae due to the lack of morphological characteristics distinctive of Rhytismataceae (Corlett and Shoemaker 1984). However, recent internal transcribed spacer (ITS) phylogenetic studies and morphology suggest Lophophacidium dooksii is closely related to L. arcuata (Laflamme et al. 2015, Ekanayaka et al. 2019). Following the phylogenetic evidence, Ekanayaka (2019) reclassified $L$. dooksii to Rhytismataceae, but the phylogenetic relationship of L. dooksii and L. arcuata with other Lophodermella species is still unclear.

The lack of molecular information on Lophodermella spp. makes it difficult to resolve intra- and interspecific phylogenetic relationships. Currently, out of the nine known Lophodermella species, only the ITS sequence of $L$. arcuata represents the genus in fungal genetic databases (i.e., NCBI-nr, UNITE, DNA Data Bank of Japan). As emerging pathogens, molecular studies on Lophodermella are important for pathogen identification. These will elucidate phylogenetic relationship of Lophodermella with other rhytismataceaous species. These will also aid in assessing the diversity and impact of emerging or invasive disease threats in conifer forest and will provide insights on fungal biology and evolution of traits. This study aims to fill this gap by analyzing the three-loci phylogeny of Lophodermella species that cause emerging needle cast 
100 diseases in western USA and Europe which include L. arcuata, L. concolor, L. conjuncta, $L$.

101

102

103

104

105

106

107

108

109

110

111

112

113

114

115

116

117

118

119

120

121

122

123

124

125

126

127

128

129

130 montivaga, and L. sulcigena. We test monophyly of this genus by including other genera within Rhytismataceae by using molecular phylogenies to guide the identification of shared and unique traits among Lophodermella species for genus and species delineation.

\section{Materials \& Methods}

\section{Sampling and morphology}

Sampling was conducted in known geographic distributions of L. arcuata, L. concolor, $L$. montivaga and L. dooksii in the USA. Similarly, L. sulcigena and L. concolor samples were collected from their known distributions in Europe. Needles from 32 P. contorta trees from natural stands infected with L. montivaga and/or L. concolor were collected in June and August 2018 across 12 sites within Gunnison National Forest, Colorado, USA (Table 1). Lophodermella arcuata on P. flexilis stands were collected from Rocky Mountain National Park, Colorado, USA in June 2018 and July 2019 while the eastern white pine (P. strobus) needles symptomatic of $L$. dooksii were collected from natural stands in Maine, USA in May 2019. Collections were approved by the USDA Forest Service, Forest Health Protection. Needles of the P. mugo infected with L. sulcigena and L. conjuncta were collected in the Swiss and Austrian Alps in 2018 (Table 1). Needles were placed into separate paper bags and stored at $4^{\circ} \mathrm{C}$ until DNA extraction.

Morphology of the fungal pathogens from randomly selected fresh symptomatic needles was characterized for fungal identification (Fig 1). Midsections of ascomata were cut using a razor blade and mounted in 3\% potassium hydroxide $(\mathrm{KOH})$. Measurements of fruiting structures were taken from mounted materials. Morphological traits common among species based on published descriptions were compared (Table 2; Corlett and Shoemaker 1984, Darker 1932, Millar and Minter 1966, 1978, Minter and Millar 1993a, Worrall et al. 2012).

\section{DNA extraction and sequencing}

Cultures from single-spore isolations of L. montivaga, L. concolor and L. arcuata were attempted but did not yield pure cultures, as these are thought to be potentially obligate fungi. Similar to previous observations (Darker 1932), mature spores isolated did not germinate and 
131 development of germ tubes in a few spores became arrested. Therefore, to be able to extract 132 adequate amounts of quality DNA, fruiting bodies from three to five symptomatic needles from 133 each tree were used for DNA extraction. DNA was extracted using a CTAB method with slight 134 modifications in tissue grinding (Cubero et al. 1999). To prepare the samples, hysterothecia were 135 cut into $1 \mathrm{~mm}$ long pieces and placed in $2 \mathrm{~mL}$ centrifuge tubes with one $5 \mathrm{~mm}$ glass bead and 136 two $2.3 \mathrm{~mm}$ metal beads. To grind the samples, the tubes were submerged in liquid nitrogen 137 before grinding using FastPrep (MP Biomedicals) for 30 seconds at speed 4 or 5 . This previous 138 process was repeated three times prior to the CTAB DNA extraction procedure developed by 139 Cubero et al. (1999). DNA quantification and purity were assessed using NanoDrop 1000 140 Spectrophotometer (Thermo Scientific). Meanwhile, the DNA extraction of L. sulcigena and $L$. 141 conjuncta samples was performed in Europe. Single fruiting bodies (ca. 3-4 mm long pieces) 142 were prepared out of dry pine needles. DNA was extracted from the lyophilized and ground fruit 143 bodies using the KingFisher/Flex Purification System (ThermoFisher Scientific) according to the 144 manufacturer's protocol and the chemicals for automated DNA extraction from fungal samples 145 with Kingfisher 96/Flex supplied by LGC Genomics GmbH (Berlin).

147 DNA was amplified at the following loci: internal transcribed spacer region 1, 5.8S ribosomal 148 RNA and internal transcribed spacer region 2 (ITS), large subunit ribosomal nucleic acid (LSU), 149 and translation elongation factor (TEF1 $\alpha$ ). Primers used include ITS1 and ITS4 (White et al. 150 1990), LROR and LR5 or LR6 (Vilaglys and Hester 1990), and EF1-983F and EFgr (Rehner 151 2001). The ITS locus was amplified at optimal annealing temperatures between $50-55^{\circ} \mathrm{C}$ with 30 cycles while TEF $1 \alpha$ and LSU were amplified at $56^{\circ} \mathrm{C}$ annealing temperature with 35 cycles

153 154 155 156 157 158 159 160 161 and other cycle parameters following Tanney and Seifert (2017). Amplification of each locus was performed in a $25-\mu \mathrm{L}$ PCR reaction mixture of $1 \times$ standard Taq reaction buffer, $0.2 \mathrm{mM}$ of each dNTP, $0.4 \mu \mathrm{M}$ of forward and reverse primer set, 0.625 units Taq polymerase, and $40 \mathrm{ng}$ template DNA. For ITS amplification, the cycle parameters included initial denaturation at $94{ }^{\circ} \mathrm{C}$ for 2 mins, followed by 30 cycles of denaturation at $94^{\circ} \mathrm{C}$ for $40 \mathrm{~s}$, optimal annealing temperature for $40 \mathrm{~s}$, extension at $72^{\circ} \mathrm{C}$ for $1 \mathrm{~min}$, and final extension at $72{ }^{\circ} \mathrm{C}$ for $5 \mathrm{mins}$.

PCR products were purified using ExoSAP-IT (Affymetrix ${ }^{\mathrm{TM}}$ ). All purified amplicons were sent to Eurofins Genomics LLC for sequencing. Additionally, cloning of PCR products for each locus 
162 was performed on at least three randomly selected $L$. concolor and L. montivaga samples using 163 pGEM ${ }^{\circledR}$ T-Easy Vector Systems (Promega) to confirm that a sequenced amplicon was of single 164 species. Three to seven clones were sequenced for each locus per sample and found to be 99.81 165 to $100 \%$ identical to the sequence of its corresponding original PCR product. Sequences were 166 compared to NCBI sequence database using the Nucleotide Basic Local Assignment Search Tool 167 (BLASTn) and were accessioned in NCBI GenBank (Table 1). Sequence data were trimmed and 168 manually checked using Geneious version R9.0.5 (Biomatters, Auckland, New Zealand) and 169 subsequently aligned using MUSCLE (Edgar 2004). Polymorphic sites were determined using 170 DnaSP (Rozas et al. 2003).

171

172 Phylogenetic analyses for each locus were constructed using Bayesian inference (MrBayes; 173 Huelsenbeck and Ronquist 2001) and maximum likelihood methods (PhyML; Guindon et al. 174 2010) as modules in Geneious v. R9.0.5. Optimal substitution models for each dataset generated 175 using DT-ModSel (Minin et al. 2003) were as follows: $S Y M+G$ for ITS, $\operatorname{TrNef}+G$ for TEF1 $\alpha$, $176 \operatorname{Tr} N+I+G$ for LSU, and $S Y M+I+G$ for the concatenated dataset. For models of evolution 177 that are not available in either MrBayes or PhyML modules, the next best complex models were 178 applied. Bayesian tree was analyzed by running Markov Chain Monte Carlo (MCMC) for up to $1791,100,000$ generations with four heated chains. Maximum likelihood tree was analyzed using 1801000 bootstraps. Bayesian and maximum likelihood trees were generated with support thresholds 181 of $80 \%$ with a $20 \%$ burn-in and $50 \%$, respectively. The phylogenies were rooted to Chalara spp. 182 (Chalara sp. MFLU 18-1812 and Chalara sp. MFLU 15-3167) following Ekanayaka et al. 183 (2019).

To evaluate the congruence of the three loci dataset, partition homogeneity test was conducted 186 using PAUP version 4.0a (Barker and Lutzoni 2002). This resulted in a $p$-value $=0.99$, indicating congruence among the ITS, LSU and TEF1 $\alpha$ datasets. Tree topologies from individual loci were also compared using the reciprocal 70\% bootstrap approach (Mason-Gamer and Kellogg 1996). Similarly, results also revealed no significant incongruence between the three datasets. Thus, the three loci dataset was combined using Sequence Matrix (Vaidya et al. 2011). The alignment and consensus tree of the concatenated dataset were stored in TreeBase

192 (Submission ID 26836). Published sequences of known related species in GenBank database 
193 were included in the phylogenetic analysis (Table S1). The rhytismataceous species were 194 selected based on similarity to Lophodermella sequences and availability in NCBI database. 195

196

197

198

199

200

201

202

203

204

205

206

207

208

209

210

211

212

213

214

215

216

217

218

219

220

221

222

223

\section{Character mapping}

Morphological characters were selected based on the presence in literature and their use for taxonomic classification of Rhytismataceae. Characters were coded based on published descriptions (Table 4; Darker 1932, 1967, Minter 1988a, Minter and Millar 1993a, 1993b, 1993c, Tanney and Seifert 2017, MycoBank 2019, Fungi and Lichens of Great Britain and Ireland 2019) and then mapped on the Bayesian ITS dataset phylogeny which had a more comprehensive set of Rhytismataceae species in well-supported clades. To assess distinct morphological characters among Lophodermella species, key characters were selected based on Darker (1932) and Hunt and Ziller (1978). These were then mapped on a separate Bayesian ITS phylogeny $(G T R+I+G$ model) that was limited to Lophodermella species and two outgroups (Elytroderma deformans and Chalara sp.). All morphological characters were coded as unordered and mapped with parsimony ancestral trace reconstruction using Mesquite v.3.6 (Maddison and Maddison 2018).

\section{Results}

Molecular and Phylogenetic Analyses

PCR amplification produced a single band for each sample per locus. Chromatograms for forward and reverse sequences did not show multiple peaks at base calls, indicating uniform amplicons. Amplicons of the ITS, TEF $1 \alpha$ and LSU yielded products that ranged from 347 to 543, 678 to 811 and 790 to 1077 base pairs, respectively. Of the 40 samples of Lophodermella species and $L$. dooksii at the ITS, a total of nine genotypes were found with 83 polymorphic (segregating) sites and 64 parsimony informative sites were observed. At the TEF1 $\alpha$, the 37 samples of Lophodermella species and L. dooksii had eight genotypes, and 77 of the 105 polymorphic sites were considered informative. Sequences of the 35 Lophodermella species and L. dooksii samples at the LSU resulted in nine genotypes with 106 total polymorphic sites and 62 parsimony informative sites. BLAST results of sequences are presented in Table S2.

Several Lophodermella species and L. dooksii clustered in a well-supported clade (hereinafter referred to as the LOD clade) at the ITS, LSU and TEF1 $\alpha$ phylogenies. This clade composed of 
224 genotypes of L. montivaga, L. concolor, L. arcuata, L. sulcigena, Lophodermella sp. and $L$. 225 dooksii in the ITS phylogeny was well-supported in the Bayesian phylogeny with a 0.96 226 posterior probability (PP), excluding L. conjuncta (Fig. S1). Similarly, for the LSU phylogeny, 227 both Bayesian and ML phylogenies produced the same clade well-supported clade (1.0 PP and 22897.9 bootstrap support (BS); Fig. S2). Lophodermella conjuncta remained distinct from the clade 229 representing all other Lophodermella species at the LSU phylogeny. At the TEF1 $\alpha$ region, LOD 230 clade had high support at 1.0 PP and 94.4 BS, (Fig. S3), but did not include both L. concolor and 231 L. conjuncta. Similar to the ITS and LSU phylogenies, the concatenated phylogeny showed all 232 Lophodermella species, except L. conjuncta, that were sampled in this study, as well as $L$. 233 dooksii, belonged to a well-supported clade with 0.99 PP and 75.5 BS support values (Fig 2). 234 Distance matrix is shown in Table S3.

235

236

Morphology and Phylogeny of Lophodermella on P. flexilis

237 Based on the phylogenetic analyses, two separate Lophodermella species were collected from $P$. 238 flexilis in the Rocky Mountain Region. Using the concatenated dataset, L. arcuata from Rocky 239 Mountain National Park (RMNP_LU1 and RMNP_LU16) clustered with L. arcuata 240 AY465518.1 from NCBI GenBank with 1.0 PP and 100 BS, whereas RMNP_01 clustered with 241 Lophophacidium dooksii samples with 0.98 PP (Figure 1). Similarly, RMNP_01 and L. dooksii 242 (MB5) were found into a cluster with $0.98 \mathrm{PP}$ and 89.9 BS, and 0.96 PP and 71.2 BS at the ITS 243 (Fig. S1) and TEF1 $\alpha$ (Fig. S3) trees respectively, indicating that RMNP_01 may represent a new 244 species, distinct from $L$. arcuata. Morphologically, sample RMNP_01 had subhypodermal 245 hysterothecia measuring $0.48-0.6 \times 0.16-0.168 \mathrm{~mm}$ and were tanned at mesophyll and 246 hypodermis. Asci were broadly saccate measuring $96-130 \times 12-14 \mu \mathrm{m}$. Ascospores were 247 clavate, measuring $58-76 \mu \mathrm{m}$ long and $3.8-4 \mu \mathrm{m}$ wide. Ascospores were also covered with 248 mucilaginous sheath (10 $\mu \mathrm{m}$ wide, Fig 3$)$. These fit the morphometric traits of L. arcuata (Table 249 2). Further, both Lophodermella sp. and L. arcuata were found on P. flexilis in similar 250 geographic location.

251

252 Shared characteristics of Lophodermella clade

253 Five traits were used in this study due to the unavailability of morphological data or unclear 254 morphological distinctions of other species within Rhytismataceae (Table 3, Table S4). The first 
255 four morphological characteristics included were those described by Darker (1967) as key

256 characteristics of species within Lophodermella. These included ascomata shape and position,

257 asci shape and ascospore shape. Host was included as an ecological trait. The only character

258 conserved within the LOD clade composed of the five Lophodermella species and L. dooksii was

259 subhypodermal ascomata position in a median transverse section (Fig 4A). All of the

260 Lophodermella species sampled in this study occur on pine hosts. The shape of ascomata or

261 hysterothecia, asci and ascospores differed within the LOD clade. Lophodermella hysterothecia

262 were mostly elliptical and elongated while hysterothecia of Lophophacidium dooksii were linear.

263 Lophodermella had clavate ascospores while ascospores of $L$. dooksii were fusiform to oval. All

264 species in the clade, except $L$. concolor, had broadly saccate to clavate asci. To measure

265 homoplasy and fit of characters, individual consistency (CI) and retention indices (RI) were

266 measured. While all morphological characters obtained an $\mathrm{RI} \geq 0.50$, only ascomata position and

267 ascospore shape had CI $\geq 0.50$, which may imply synapomorphy of the two characters (Fig. 4).

268

269 Distinct characters were observed across Lophodermella species, which may be useful for 270 species identification and delineation (Fig. 5, Table S5). Short and concolorous hysterothecia

271 were distinct in L. concolor while elongated clavate ascospore and fused hysterothecia were

272 distinct in L. conjuncta. The fusiform to oval ascospore was unique to Lophophacidium dooksii.

273 Meanwhile, L. montivaga, Lophodermella sp. (RMNP_01) and L. sulcigena only differed at their

274 host occurrence. Hysterothecia of L. arcuata was reported to be concolorous when dry as

275 opposed to that of Lophodermella sp. (RMNP_01) which remains dark brown. All of the six

276 characters for species delineation generated a mean CI and RI of 0.95 and 0.92 , respectively.

277

\section{Discussion}

279 This study revealed a well-supported clade consisting of several Lophodermella species

280 including L. montivaga, L. concolor, L. arcuata, L. sulcigena, and Lophodermella sp. within

281 Rhytismataceae. Lophodermella conjuncta, however, was consistently placed outside of this

282 clade. In all phylogenies, Lophophacidium dooksii consistently clustered within the LOD clade.

283 Despite highly similar morphological characteristics, this study showed that Lophodermella

284 pathogens are molecularly distinct from each other and may represent more genetic diversity 
285 than previously thought. This study also identified shared characteristics within the LOD clade 286 and explored on morphological characters that could be useful in taxon classification.

287

288

Molecular and Phylogenetic Analyses of Lophodermella

289

290

291

292

293

294

295

296

297

298

299

300

301

302

303

304

305

306

307

308

309

310

311

312

313

314

A concatenated dataset of the three loci clearly separated L. montivaga and L. concolor that both infect $P$. contorta and distinguished the Lophodermella species from other closely related fungi. Lophodermella montivaga, L. concolor, L. arcuata, L. sulcigena, Lophodermella sp. and Lophophacidium dooksii formed the LOD clade, which were distinct from species within the genera Lophodermium (Ortiz-Garcia et al. 2003) and Spathularia-Cudonia (Ge et al. 2014). However, in the TEF1 $\alpha$ phylogeny, L. concolor was excluded from the LOD clade, but was placed in the clade at the LSU and ITS phylogenies. This could be attributed to a fewer number of sequenced Rhytismataceae species resulting in low phylogenetic resolution or other genetic loci may best represent the species phylogeny. While additional sequences at each locus would likely improve phylogenetic resolution, whole-genome sequencing would provide greater advantage in phylogenetic reconstruction as well as gain deeper evolutionary perspectives on rhytismataceous needle pathogens.

Exclusion of L. conjuncta in the LOD clade may suggest polyphyly of the genus. This is the first report of the potential polyphyly of Lophodermella within Rhytismataceae. Polyphyletic genera are commonly observed within Rhytismatales partly due to the use of distinctive yet nonsynapomorphic characters for generic-level classification (Lantz et al., 2011). Lophodermium is an example of a polyphyletic genus that appears in the radiate, bilateral and Picea-associated clades (2011). Reorganization of Lophodermium was not possible due to the wide diversity of species in the group (Darker 1967). Monophyletic genera also exist within Rhytismataceae that includes Cudonia and Terriera (Lantz et al., 2011). However, this present study does not disregard potential changes in the phylogenetic arrangement and polyphyly as more Lophodermella species will be genetically investigated. Increased sampling of species within the two genera provided further evidence of Cudonia as a monophyletic genus but suggested that Spathularia was polyphyletic (Ge et al. 2014). It may also be possible that $L$. conjuncta belong to a separate genus that shares close morphological and phylogenetic relationship with 
315 Lophodermella. Thus, further investigation of other Lophodermella species which so far have no 316 available sequence data still needs to be conducted to confirm these phylogenetic arrangements.

317

318

319

320

321

322

323

324

325

326

327

328

329

330

331

332

333

334

335

336

337

338

339

340

341

342

343

(34) 344 sp. from P. flexilis collected at RMNP as it did not cluster together with L. arcuata samples. 345 Aside from morphometric features, initial examination identified RMNP_01 sample as $L$.

The present study supported a close relationship of L. montivaga and L. sulcigena compared to the other species within the LOD clade. Darker (1932) speculated that L. sulcigena from Europe may be identical to L. montivaga due to morphological similarities. Despite the overlapping morphological distinctions between the two species, this present study provided molecular evidence that L. montivaga and L. sulcigena are two distinct species. Another previous speculation was the possibility that L. arcuata is a variety of either L. montivaga or L. sulcigena owing to its resemblance to both species and its limited occurrence (Darker 1932). However, symptom and ascocarp development in both species were different and thus were maintained as two different species (Millar 1984). Genetic evidence gave support that L. arcuata is distinct from L. sulcigena and L. montivaga.

Consistent nesting of Lophophacidium dooksii in a Lophodermella clade was observed in all phylogenies, which concurs with a previous molecular study (Laflamme et al. 2015). Results herein showed that L. dooksii is more closely related to Lophodermella sp. (from P. flexilis) than to L. montivaga and L. arcuata, and provides more evidence for the transfer of the species from Phacidiaceae to Rhytismataceae as proposed by Ekanayaka et al. (2019). We did not attempt to reclassify the taxon to Lophodermella since we did not have large sample size and type specimen to conduct further validations. Interestingly, L. dooksii was synonymous to Canavirgella banfieldii, a species classified under Rhytismataceae, but the former taxonomic name was given priority due to its earlier publication (Laflamme et al. 2015). In other studies, use of multiple loci supported the placement of Cudonia and Spathularia from Geoglossaceae to Rhytismataceae (Gernandt et al. 2001, Lantz et al. 2011, Ge et al. 2014), which these results also support (Fig. S1-3).

Phylogeny of Lophodermella sp. from P. flexilis

Individual phylogenies in this study could not confirm the species identity of the Lophodermella 
346 arcuata due to its occurrence on P. flexilis in Colorado. Minter and Millar (1993) considered

347 host preference and geographic distribution as criteria for identification of $L$. arcuata due to the 348 consistent reports on this species being the only member of the genus occurring on five-needle 349 pines in North America. However, genetic data suggests Lophodermella sp. may represent a 350 separate species distinct from $L$. arcuata. Since needle samples with this potentially new species 351 were only collected from one tree, we did not attempt to formally name the species but 352 temporarily named at the genus level as Lophodermella. Further investigation needs to be 353 conducted to differentiate this species with other Lophodermella species described in literature 354 and to define the population diversity of $L$. arcuata. Further, results from this study also suggest 355 that undescribed cryptic Lophodermella species exist on pine hosts.

356

357

Morphological and Lifestyle Traits of the Lophodermella clade

358

Classification of Rhytismataceae genera has been challenged by the limited morphological

359 features for characterization. Darker (1967) revised the genera within the previous Hypodermataceae based on the characteristics of their ascomata or hysterothecia, asci, and pycnidia or a combination of these characters. Spore shape, septation and color were secondary characters to delimit the genera (Darker 1967). Further, Lantz et al. (2011) described ascomata and spores as unreliable characters for genus delimitation in Rhytismatales but found that a combination with other traits was potentially useful. This study showed that, at the genus level, subhypodermal ascomata and ascospore shape may be used as diagnostic characters for delimitation of genus Lophodermella. This is congruent to the dichotomous key produced by Darker (1967) to delimit this genus. Despite its inclusion in the LOD clade, Lophophacidium dooksii did not have clavate ascospores but rather had ascospores with fusiform to oval shape. Interestingly, aside from subhypodermal hysterothecia, all species within the LOD clade produced a tanned hypodermis. Furthermore, despite low consistency, the strong retention of asci shape may also suggest its role in taxa distinction.

373 Within Lophodermella genus, morphometric traits such as size of ascospores and hysterothecia 374 are still used as distinctive characters. This study showed that a combination of morphological 375 and ecological characters may be used to distinguish Lophodermella species, particularly 376 ascospore and hysterothecia length, hysterothecia color, and the number of needles on pine host. 
377 However, these characters may also become problematic in practice. For example, while

378 ascospore size was identified as a reliable criterion, measurements of spores varied depending on

379 the freshness of specimen and thus cannot easily be used for identification of Lophodermella

380 species (Millar 1984). Further, concolorous hysterothecia as key character may be misleading as

381 some species can also produce conspicuous hysterothecia (Millar 1984).

382

383 Difficulty in obtaining pure cultures of L. montivaga, L. concolor and L. dooksii can also

384 potentially limit further characterization of other traits such as physiology and pathogenicity.

385 Similar to other studies, we were not able to grow in culture the Lophodermella species sampled

386 in this study, suggesting an obligate lifestyle. Use of agar cultures including pine extract agar did

387 not yield successful cultures of Lophodermella (Millar 1984). Some studies also described $L$.

388 dooksii and Bifusella linearis as obligate fungal pathogens after unsuccessful attempts of

389 obtaining cultures or only obtaining short-lived cultures (Broders et al. 2015, Merrill et al. 1996).

390 In contrast, previous studies were able to isolate pure cultures of $L$. sulcigena on malt agar

391 (Jalkanen 1985, Kowalski and Krygier 1996). Similarly, a number of studies documented several

392 Lophodermium species (e.g., Decker et al. 2001, Wilson et al. 1994) growing in 2\% malt extract

393 agar. Elytroderma deformans needed an acidic pine decoction agar substrate or an addition of

394 pine needle extracts to significantly grow in culture (Laurent 1962, Legge 1964). Consequently,

395 while environmental DNA may be available, the absence of pure cultures of many

396 Lophodermella species limit further molecular research that require a high pure DNA

397 concentration.

398

399 Most Lophodermella species appear to be either specific to a single host species distributed in a 400 certain geographic region (i.e., L. maureri on P. ayacahuite in Mexico and L. orientalis on $P$.

401 kesiya in Asia) or to a group of host species within a Pinus classification with similar number of 402 needles (i.e., L. sulcigena and L. conjuncta on two-needle pines of subsection Pinus in Europe, 403 and L. concolor on two-needle pines of subgenus Pinus in western North America; Millar 1984, 404 Gernandt et al. 2005). Furthermore, L. arcuata and L. maureri are the only two Lophodermella 405 species on five-needle pines of subsection Strobus while L. morbida only occurs exclusively on 406 three-needle pines under section Trifoliae. In contrast, L. cerina was reported to have a broader 407 host range occurring on two- to three-needle Pinus species in sections Trifoliae and Pinus 
408 (subgenus Pinus; Millar 1984, Gernandt et al. 2005). Lophodermella montivaga was also 409 documented on two- to five-needle Haploxylon and Diploxylon pines. In this study, genetic 410 information was used to verify the association of Lophodermella species with a known host. It 411 allowed us to identify additional species on $P$. flexilis that would have otherwise been classified 412 as L. arcuata based on its morphology and host association. Thus, it can serve as a tool to assess 413 the extent of these fungal species across different hosts in different geographic regions.

414

415 Conclusion

416 This study sequenced and characterized emerging Lophodermella needle cast pathogens on 417 Pinus in North America and Europe. It highlights a distinct clade composed of Lophodermella 418 species and Lophophacidium dooksii within Rhytismataceae. Further, this study also observed a 419 Lophodermella species on P. flexilis that is morphologically similar yet genetically distinct from 420 L. arcuata, which suggests presence of undescribed cryptic Lophodermella species. Further 421 investigations of Lophodermella species using advanced molecular tools can also help answer 422 genetic, evolutionary and ecological inquiries such as on population structure, pathogenicity, 423 host specialization, hybridization, and other biological inferences.

424

\section{Acknowledgements}

426 The authors also thank Aaron Bergdahl and Wayne Searles of Maine Forest Service, and Jessica 427 Cancelliere of New York State Department of Environmental Conservation for their assistance in 428 Lophophacidium dooksii sample collection. The authors are also grateful to the USFS Northern 429 Research Station for access to the Massabesic Experimental Forest. Dr. Jorge Ibarra Caballero 430 assisted in DNA extraction and sample collection in Colorado. The authors also thank Dr.

431 Thomas L Cech (Vienna) for his assistance in the European Lophodermella collection. The 432 molecular work on the European specimens was carried out in the WSL plant protection 433 laboratory (Birmensdorf, $\mathrm{CH}$ ) - many thanks to its staff for the helpful assistance.

434

435 References

436 Barker FK, Lutzoni FM. 2002. The Utility of the incongruence length difference test. Systematic 437 Biology. 51: 625-637. 
438

439 Barnes I, Wingfield MJ, Carbone I, Kirisits T, Wingfield BD. 2014. Population structure and 440 diversity of an invasive pine needle pathogen reflects anthropogenic activity. Ecology and 441 Evolution. 4 (18): 3642-3661.

442

443 Beenken L. 2019. Lophodermella-Nadelschütte (pp. 18-19). In Queloz V, Forster B, Beenken L, 444 Stroheker S, Odermatt O, Hölling D, Meyer JB, Dubach V. Waldschutzüberblick 2018. WSL 445 Berichte 79: 1-33. https://www.wsl.ch/de/publikationen/waldschutzueberblick-2018.html

446

447

Broders K, Munck I, Wyka S, Iriarte G, Beaudoin E. 2015. Characterization of fungal pathogens 448 associated with White Pine Needle Damage (WPND) in Northeastern North America. Forests. 6, 449 4088-4104. doi: 10.3390/f6114088.

450

451

Brodde L, Adamson K, Camarero JJ, Castaño C, Drenkhan R, Lehtijärvi A, Luchi N, Migliorini 452 D, Sanchez-Miranda A, Stenlid J, Özdag S, Oliva J. 2018. Diplodia tip blight on its way to the 453 north: drivers of disease emergence in northern Europe. Frontiers in Plant Science. 9: 1818.

454

455 Corlett M, Shoemaker RA. 1984. Lophophacidium dooksi n. sp., a phacidiaceous fungus on 456 needles of white pine. Canadian Journal of Botany. 62, 1836-1840.

457 Czabator FJ, Staley, JM, Snow GA. 1971. Extensive southern pine needle blight during 1970458 1971, and associated fungi. Plant Disease Reporter, 55: 764-766.

459

460 Cubero OF, Crespo A, Fatehi J, Bridge PD. 1999. DNA extraction and PCR amplification 461 method suitable for fresh, herbarium-stored, lichenized and other fungi. Plant Systematics and 462 Evolution, 216: 243-249.

463

464

Darker G. 1932. The Hypodermataceae of Conifers. Contributions from the Arnold Arboretum 465 of Harvard University. 1:1-131.

466

467 Darker G. 1967. A revision of the genera of the Hypodermataceae. Canadian Journal of Botany. 468 45, 1399-1444. 
469

470 Decker RJ, Hsiang T, Peterson RL. 2001. Genetic relationships of endophytic Lophodermium 471 nitens isolates from needles of Pinus strobus. Mycological Research. 106 (3), 305-313. doi:

$47210.1017 / \mathrm{S} 0953756201005494$

473

474 Edgar RC. 2004. MUSCLE: multiple sequence alignment with high accuracy and high 475 throughput. Nucleic Acids Research 32: 1792-1797. pmid:15034147

476

477 Ekanayaka AH, Hyde KD, Gentekaki E, McKenzie EHC, Zhao Q, Bulgakov TS, Camporesi E. 478 2019. Preliminary classification of Leotiomycetes. Mycosphere. 10 (1): 310-489.

479

480 Fungi and Lichens of Great Britain and Ireland. http://fungi.myspecies.info. Last Accessed 6 481 August 2019.

482

483 Funk A. 1985. Foliar fungi of western trees. Information Report BC-X-265. Victoria, BC.:

484 Agriculture Canada, Ministry of State for Forestry, Pacific Forest Research Centre. 159 p.

485

486 Ge Z-W, Yang ZL, Pfister DH, Carbone M, Bau T, Smith ME. 2014. Multigene molecular 487 phylogeny and biogeographic diversification of earth tongue fungi in the genera Cudonia and 488 Spathularia (Rhytismatales, Ascomycota). PLoS ONE. 9 (8): e103457. doi:

489 10.1371/journal.pone.0103457.

490

491 Gernandt DS, Geada López G, Ortiz García S, Liston A. 2005. Phylogeny and classification of 492 Pinus. Taxon, 54 (1): 29-42.

493

494 Gernandt DS, Platt JT, Stone JK, Spatafora JW, Holst-Jensen A, Hamelin RC, Kohn LM. 2001. 495 Phylogenetics of Helotiales and Rhytismatales based on partial small subunit nuclear ribosomal 496 DNA sequences. Mycologia. 93 (5): 915-933.

497 
498 Gray LK, Russell JH, Yanchuk AD, Hawkins BJ. 2013. Predicting the risk of cedar leaf blight 499 (Didymascella thujina) in British Columbia under future climate change. Agricultural and Forest 500 Meteorology. 180: 152- 163.

501

502 Guindon S, Dufayard JF, Lefort V, Anisimova M, Hordijk W, Gascuel O. 2010. New algorithms 503 and methods to estimate maximum-likelihood phylogenies: assessing the performance of PhyML 504 3.0. Syst. Biol. 59 (3): 307-321. doi: 10.1093/sysbio/syq010

505

506 Huelsenbeck JP, Ronquist F. 2001. MRBAYES: Bayesian inference of phylogenetic trees.

507 Bioinformatics. 17 (8): 754-757. doi.org/10.1093/bioinformatics/17.8.754

508

509 Hunt RS, Ziller WG. 1978. Host-genus keys to the Hypodermataceae of conifer leaves.

510 Mycotaxon. $6(3):$ 481-496.

511

512 Jalkanen R. 1985. The occurrence and importance of Lophodermella sulcigena and Hendersonia 513 acicola on Scots pine in Finland. Karstenia. 25: 53-61.

514

515 Kowalski T, Krygier J. 1996. Mycological study on symptomless and diseased needles in pine 516 stand attacked by Lophodermella sulcigena (Rostr.) V. Höhn. Phytopathologia Polonica. 11: 517 159-168.

518

519 Laflamme G, Broders K, Côté C, Munck I, Iriarte G, Innes L. 2015. Priority of Lophophacidium 520 over Canavirgella: taxonomic status of Lophophacidium dooksii and Canavirgella banfieldii, 521 causal agents of a white pine needle disease. Mycologia. 107 (4): 745-753. doi: 10.3852/14-096. 522

523 Lantz H, Johnston PR, Park D, Minter DW. 2011. Molecular phylogeny reveals a core clade of 524 Rhytismatales. Mycologia. 103 (1): 57-74. doi: 10.3852/10-060.

525

526 Laurent TH. 1962. Studies of the developmental morphology and life history of Elytroderma 527 deformans. Graduate Student Theses, Dissertations, \& Professional Papers. 6778.

528 https://scholarworks.umt.edu/etd/6778

PeerJ reviewing PDF | (2021:01:57289:1:1:NEW 16 Apr 2021) 
529

530 Lee EH, Beedlow PA, Waschmann RS, Tingey DT, Cline S, Bollman M, Wickham C, Carlile C.

531 2017. Regional patterns of increasing Swiss needle cast impacts on Douglas-fir growth with

532 warming temperatures. Ecology and Evolution. 7 (24): 11167-11196.

533

534 Legge TW. 1964. A partial characterization of Elytroderma deformans. Unpublished Master of

535 Science Thesis Dissertation. University of Montana, Montana, USA.

536 Lotan, J.E. and W.B. Critchfield. 1990. Pinus contorta Dougl. ex Loud. Pp. 302-315 in R.M.

537 Burns and B.H. Honkala (technical coordinators). Silvics of North America, Vol. 1. USDA

538 Agriculture Handbook No. 654, Washington, D.C.

539 Maddison WP, Maddison DR. 2018. Mesquite: a modular system for evolutionary analysis.

540 Version 3.51. http://mesquiteproject.org

541

542 Merrill W, Wenner NG, Dreisbach TA. 1996. Canavirgella banfieldii gen. and sp. nov.: a

543 needle-cast fungus on pine. Can J Bot 74:1476-1481.

544

545 Millar CS. 1984. Lophodermella species on pines. In: Proceedings of the IUFRO Working Party 546 Conference on Recent Research on Conifer Needle Diseases. Gulfport, Mississippi, October 14$54718,1984$.

548

549 Millar CS, Minter DW. 1966. Lophodermella conjuncta. CMI Descriptions of Pathogenic Fungi 550 and Bacteria, set no. 66, no. 658.

551

552 1978. Lophodermella sulcigena. CMI Descriptions of Pathogenic Fungi and

553 Bacteria, set no. 57, no. 562.

554

555 Minin, V, Abdo Z, Joyce P, Sullivan J. 2003. Performance-based selection of likelihood models

556 for phylogeny estimation. Systematic Biology, 52: 674-683.

557 
558 Minter DW. 1988a. CMI Descriptions of Pathogenic Fungi and Bacteria no. 942. Colpoma

559 quercinum. Mycopathologia 102 (1): 53-54.

560

561

----------. 1988b. CMI Descriptions of Pathogenic Fungi and Bacteria no. 945. Lophodermella

562 maureri. Mycopathologia 102 (1): 59-60

563

564

------------. 1993. IMI Descriptions of Fungi and Bacteria no. 1148. Lophodermella

565 orientalis. Mycopathologia 121 (1): 57-58.

566

567

Minter DW, Millar CS. 1993a. IMI Descriptions of Fungi and Bacteria no. 1144. Lophodermella

568 arcuata. Mycopathologia 121 (1): 49-50.

569

570 1993b. IMI Descriptions of Fungi and Bacteria no. 1146. Lophodermella 571 concolor. Mycopathologia 121 (1): 53-54.

572

573 1993c. IMI Descriptions of Fungi and Bacteria no. 1147. Lophodermella

574 montivaga. Mycopathologia 121 (1): 55-56.

575

576

[-------------. 1993d. IMI Descriptions of Fungi and Bacteria no. 1145. Lophodermella

577 cerina. Mycopathologia 121 (1): 51-52.]

578

579 MycoBank Database. 2016. http://mycobank.org. Last Accessed: 4 August 2019.

580

581 Ortiz-Garcia S, Gernandt DS, Stone JK, Johnston PR, Chapela IH, Salas-Llanza R, Alvarez-

582 Buylla E. 2003. Phylogenetics of Lophodermium. Mycologia. 95 (5): 846-859. doi:

$583 \quad 10.1080 / 15572536.2004 .11833044$

584

585 Owens JN. 2006. The reproductive biology of lodgepole pine. Forest Genetics Council of British 586 Columbia.

587 
588 Pearson JA, Fahey TJ and Knight DH. 1984. Biomass and leaf area in contrasting lodgepole pine 589 forests. Canadian Journal of Forest Research. 14 (2): 259-265.

590

591 Rehner SA. 2001. EF1-alpha primers. USDA, ARS, PSI Insect Biocontrol Laboratory. Available 592 from http://www.aftol.org/ pdfs/EF1primer.pdf.

593

594 Rodas CA, Wingfield MJ, Granados GM, Barnes I. 2016. Dothistroma needle blight: an 595 emerging epidemic caused by Dothistroma septosporum in Columbia. Plant Pathology. 65 (1): $59653-63$.

597

598

Rozas J, Sánchez-Del Barrio JC, Messeguer X, Rozas, R. 2003. DnaSP, DNA polymorphism 599 analyses by the coalescent and other methods. Bioinformatics. 19: 2496-2497

600

601 Schoettle AW. 2004. Ecological roles of five-needle pines in Colorado: potential consequences 602 of their loss. In: Sniezko RA, Samman S, Schlarbaum SE, Kriebel HB. eds. 2004. Breeding and 603 genetic resources of five-needle pines: growth, adaptability and pest resistance; 2001 July 23-27; 604 Medford, OR, USA. IUFRO Working Party 2.02.15. Proceedings RMRS-P-32. Fort Collins, CO: 605 U.S. Department of Agriculture, Forest Service, Rocky Mountain Research Station.

606

607 Staley JM, Bynum HH. 1972. A new Lophodermella on Pinus ponderosa and P. attenuata.

608 Mycologia. 64 (4): 722-726.

609

610 Tanney JB, Seifert KA. 2017. Lophodermium resinosum sp. nov. from red pine (Pinus resinosa) 611 in Eastern Canada. Botany. 95: 773-784. dx.doi.org/10.1139/cjb-2017-0012

612

613 Vaidya G, Lohman DJ and Meier R. 2011. SequenceMatrix: concatenation software for the fast 614 assembly of multi-gene datasets with character set and codon information. Cladistics. 27: 171615180.

616 
617 Vilgalys R, Hester M. 1990. Rapid genetic identification and mapping of enzymatically

618 amplified ribosomal DNA from several Cryptococcus species. J. Bacteriol. 172 (8): 4238- 4246.

619 doi:10.1128/jb.172.8.4238-4246.1990.

620

621 Welsh C, Lewis K, Woods A. 2014. Regional outbreak dynamics of Dothistroma needle blight

622 linked to weather patterns in British Columbia, Canada. Canadian Journal of Forest Research.

623 44: 212-219

624

625 White TJ, Bruns T, Lee S, Tayolor JW. 1990. Amplification and direct sequencing of fungal

626 ribosomal RNA genes for phylogenetics. In: PCR Protocols: A Guide to Methods and

627 Applications. Edited by: Innis MA, Gelfand DH, Sninsky JJ, White TJ. 1990, New York:

628 Academic Press Inc, 315-322.

629

630 Wilson R, Wheatcroft R, Miller JD, Whitney NJ. 1994. Genetic diversity among natural 631 populations of endophytic Lophodermium pinastri from Pinus resinosa. Mycological Research. 63298 (7): 740-744.

633

634 Woods AJ. 2014. Warmer and wetter might not be better - short review. Journal of Forest 635 Science, 60 (11): 484-486

636

637 Woods AJ, Coates KD, Hamann A. 2005. Is an unprecedented Dothistroma needle blight 638 epidemic related to climate change? BioScience. 55 (9): 761-769.

639

640 Worrall JJ, SB Marchetti, RA Mask. 2012. An epidemic of Lophodermella needle cast on 641 lodgepole pine in Colorado. USDA Forest Service, Rocky Mountain Region, Forest Health 642 Protection. Biological Evaluation R2-12-01.

643

644 Wyka, SA, Munck, IA, Brazee, NJ, Broders, KD. 2018. Response of eastern white pine and 645 associated foliar, blister rust, canker and root rot pathogens to climate change. Forest Ecology 646 and Management. 423: 18-26.

647 
648 Wyka SA, Smith C, Munck IA, Rock BN, Ziniti BL, Broders K. 2017. Emergence of white pine 649 needle damage in the northeastern United States is associated with changes in pathogen pressure 650 in response to climate change. Global Change Biology. 23 (1): 394-405

651

652 Figure Legend:

653

654 Figure 1 - Ascomata of Lophodermella concolor (a) and L. montivaga (b) on Pinus contorta 655 from Gunnison National Forest, Colorado, USA; Lophodermella sp. (c) and Lophodermella 656 arcuata (d) on P. flexilis from Rocky Mountain National Park, Colorado, USA; Lophophacidium 657 dooksii on P. strobus from Massabesic, Maine, USA (e); and L. conjuncta (f) and L. sulcigena 658 (g) on P. mugo from Austria and Switzerland.

659

660 Figure 2 - Maximum likelihood phylogeny depicting phylogenetic relationships of

661 Lophodermella species within Rhytismataceae based on three gene regions including the internal 662 transcribed spacer (ITS), large ribosomal subunit (LSU) and translation elongation factor 1-alpha 663 (TEF1 $\alpha$ ). Bayesian posterior probabilities (PP) greater than 0.80 and bootstrap (BS) support 664 values from maximum likelihood analysis greater than 50 are shown above and below node, 665 respectively. Species in bold are samples derived from this study. Numbers correspond to 666 genotypes after concatenation.

667

668 Figure 3 - Morphological characters of Lophodermella sp. on Pinus flexilis collected from 669 Rocky Mountain National Park, Colorado, USA. Subhypodermal hysterothecia with tanned 670 mesophyll and hypodermis (a, d), clavate ascospores with gelatinous sheath (b) and broadly 671 saccate asci (c). Size bars a, c and d $20 \mu \mathrm{m} ; \mathrm{b} 10 \mu \mathrm{m}$.

672

673 Figure 4 - Morphological characters mapped onto ITS phylogenetic tree with the parsimony 674 ancestral reconstruction method using Mesquite v.3.6 with retention indices $\geq 0.50$, ascomata 675 position (a) and ascospore shape (b).

676 
677 Figure 5 - Morphological characters mapped onto Bayesian ITS phylogenetic tree with the

678 parsimony ancestral reconstruction method using Mesquite v.3.6, fusion of ascomata (a) and 679 number of needles of pine host (b). 


\section{Figure 1}

Ascomata of Lophodermella concolor (a) and L. montivaga (b) on Pinus contorta from Gunnison National Forest, Colorado, USA

Ascomata of Lophodermella concolor (a) and L. montivaga (b) on Pinus contorta from Gunnison National Forest, Colorado, USA; Lophodermella sp. (c) and Lophodermella arcuata (d) on P. flexilis from Rocky Mountain National Park, Colorado, USA; Lophophacidium dooksii on P. strobus from Massabesic, Maine, USA (e); and L. conjuncta (f) and L. sulcigena ( $g$ ) on $P$. mugo from Austria and Switzerland. 


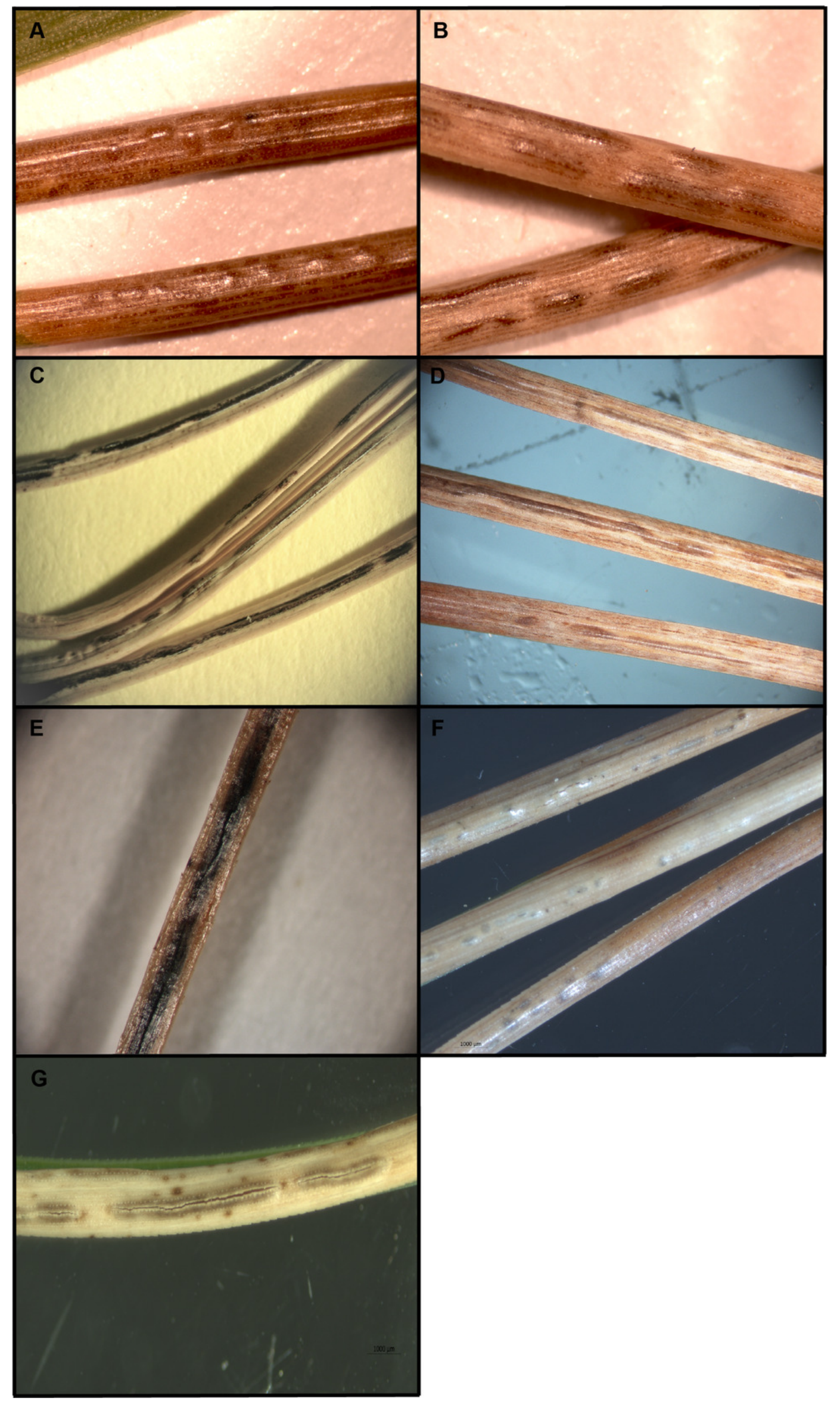

PeerJ reviewing PDF | (2021:01:57289:1:1:NEW 16 Apr 2021) 


\section{Figure 2}

Maximum likelihood phylogeny depicting phylogenetic relationships of Lophodermella species within Rhytismataceaebased on three gene regions including the internal transcribed spacer (ITS), large ribosomal subunit (LSU) and translation elongation fac

Maximum likelihood phylogeny depicting phylogenetic relationships of Lophodermella species within Rhytismataceaebased on three gene regions including the internal transcribed spacer (ITS), large ribosomal subunit (LSU) and translation elongation factor 1-alpha (TEF1a). Bayesian posterior probabilities (PP) greater than 0.80 and bootstrap (BS) support values from maximum likelihood analysis greater than 50 are shown above and below node, respectively. Species in bold are samples derived from this study. Numbers correspond to genotypes after concatenation. 


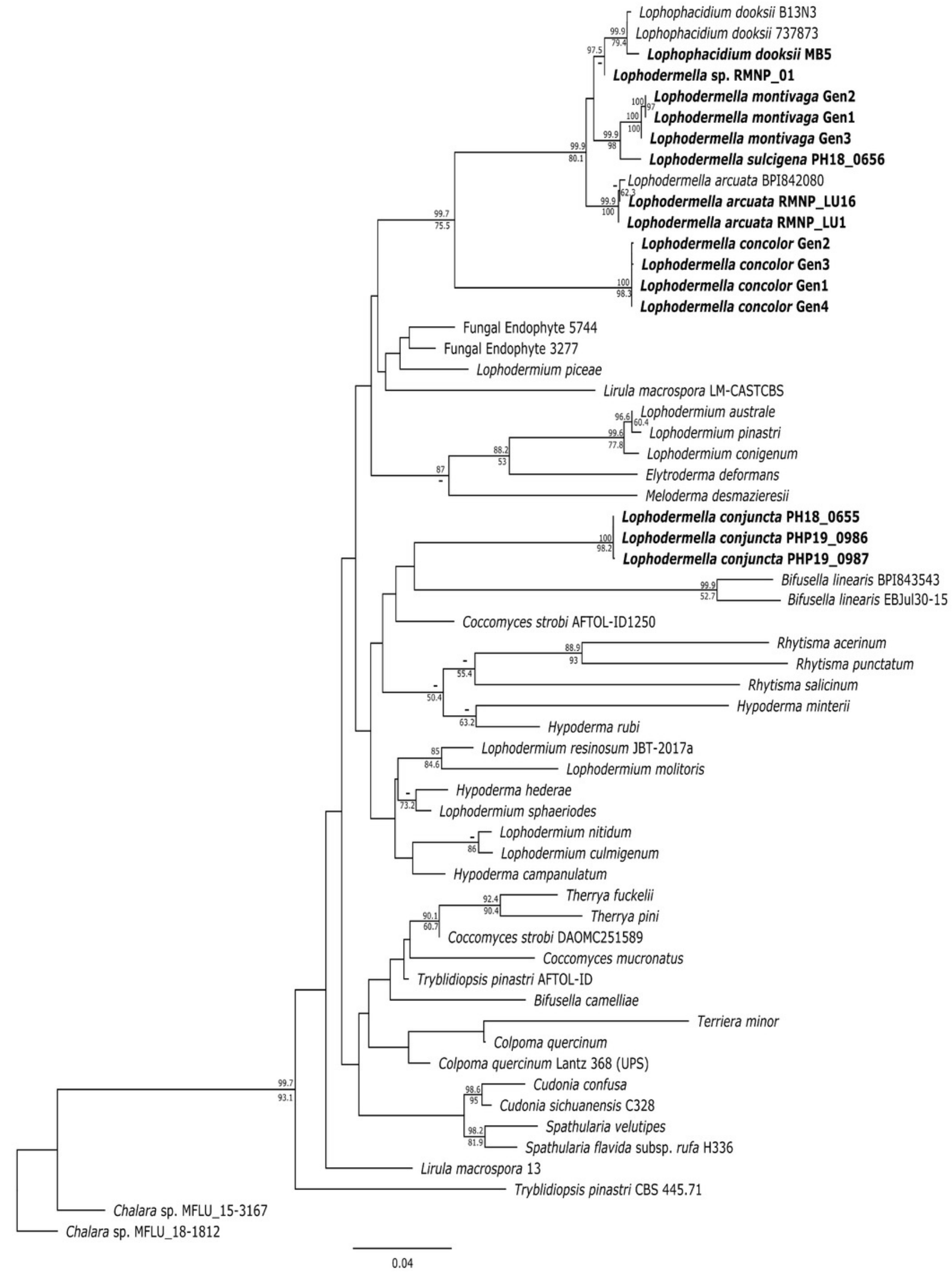




\section{Figure 3}

Morphological characters of Lophodermella sp. on Pinus flexilis collected from Rocky Mountain National Park, Colorado, USA.

Morphological characters of Lophodermella sp. on Pinus flexilis collected from Rocky Mountain National Park, Colorado, USA. Subhypodermal hysterothecia with tanned mesophyll and hypodermis (a, d), clavate ascospores with gelatinous sheath (b) and broadly saccate asci (c). Size bars a, c and d $20 \mathrm{~mm}$; b $10 \mathrm{~mm}$. 

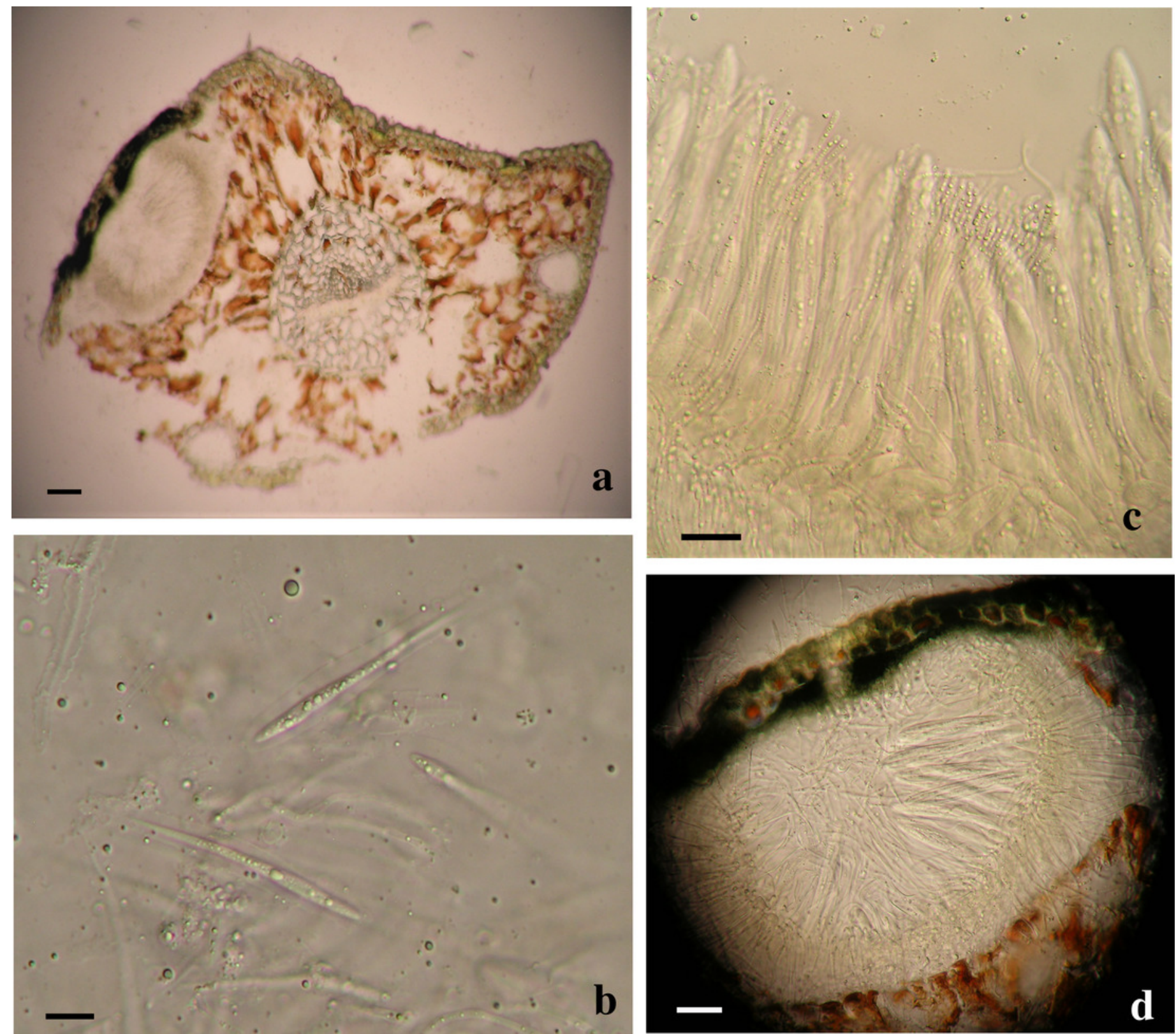
Figure 4

Morphological characters mapped onto ITS phylogenetic tree with the parsimony ancestral reconstruction.

Morphological characters mapped onto ITS phylogenetic tree with the parsimony ancestral reconstruction method using Mesquite v.3.6 with retention indices $\geq 0.50$, ascomata position (a) and ascospore shape (b). 

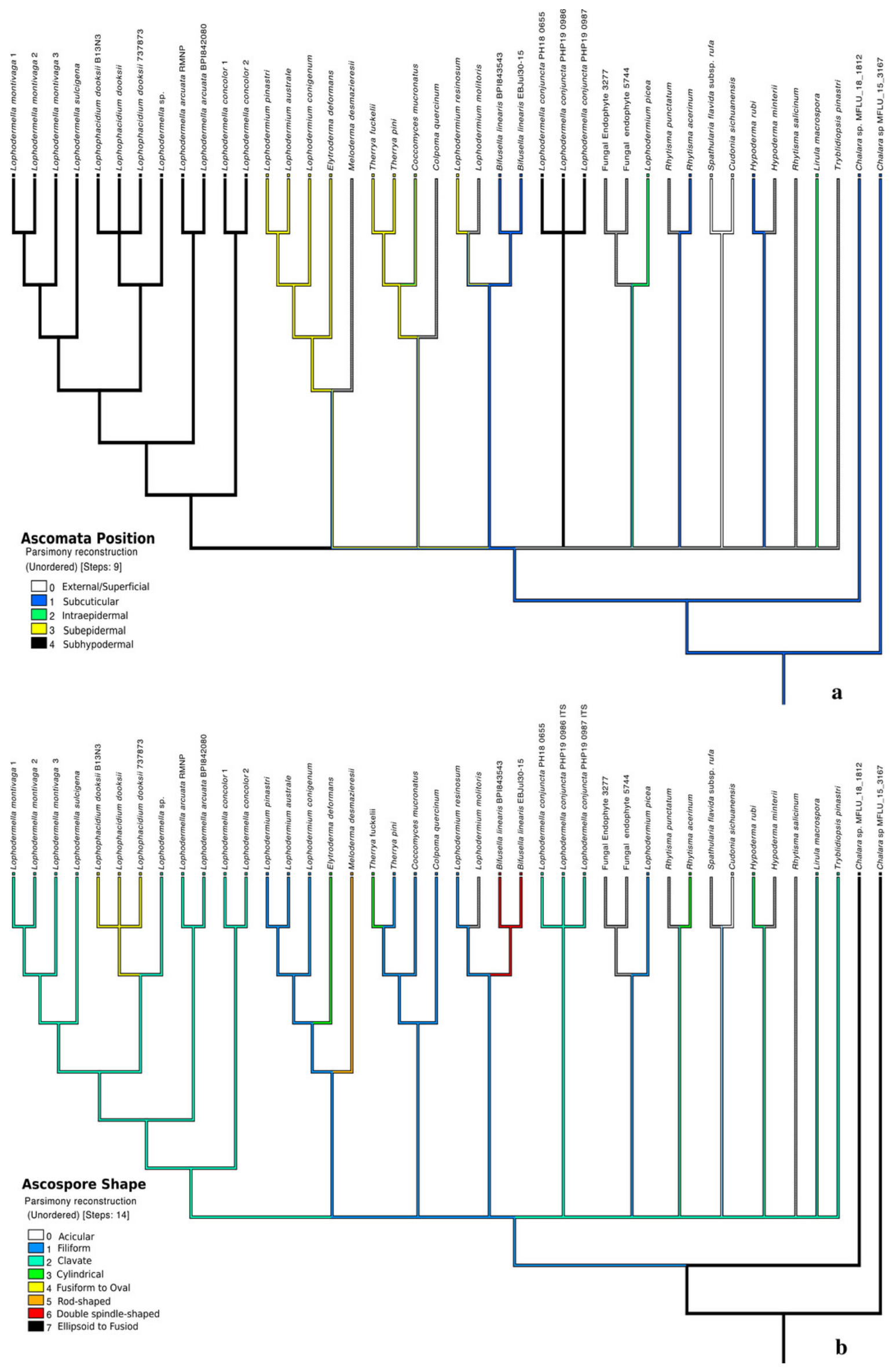
Figure 5

Morphological characters mapped onto Bayesian ITS phylogenetic tree with the parsimony ancestral reconstruction method.

Morphological characters mapped onto Bayesian ITS phylogenetic tree with the parsimony ancestral reconstruction method using Mesquite v.3.6, fusion of ascomata (a) and number of needles of pine host (b). 

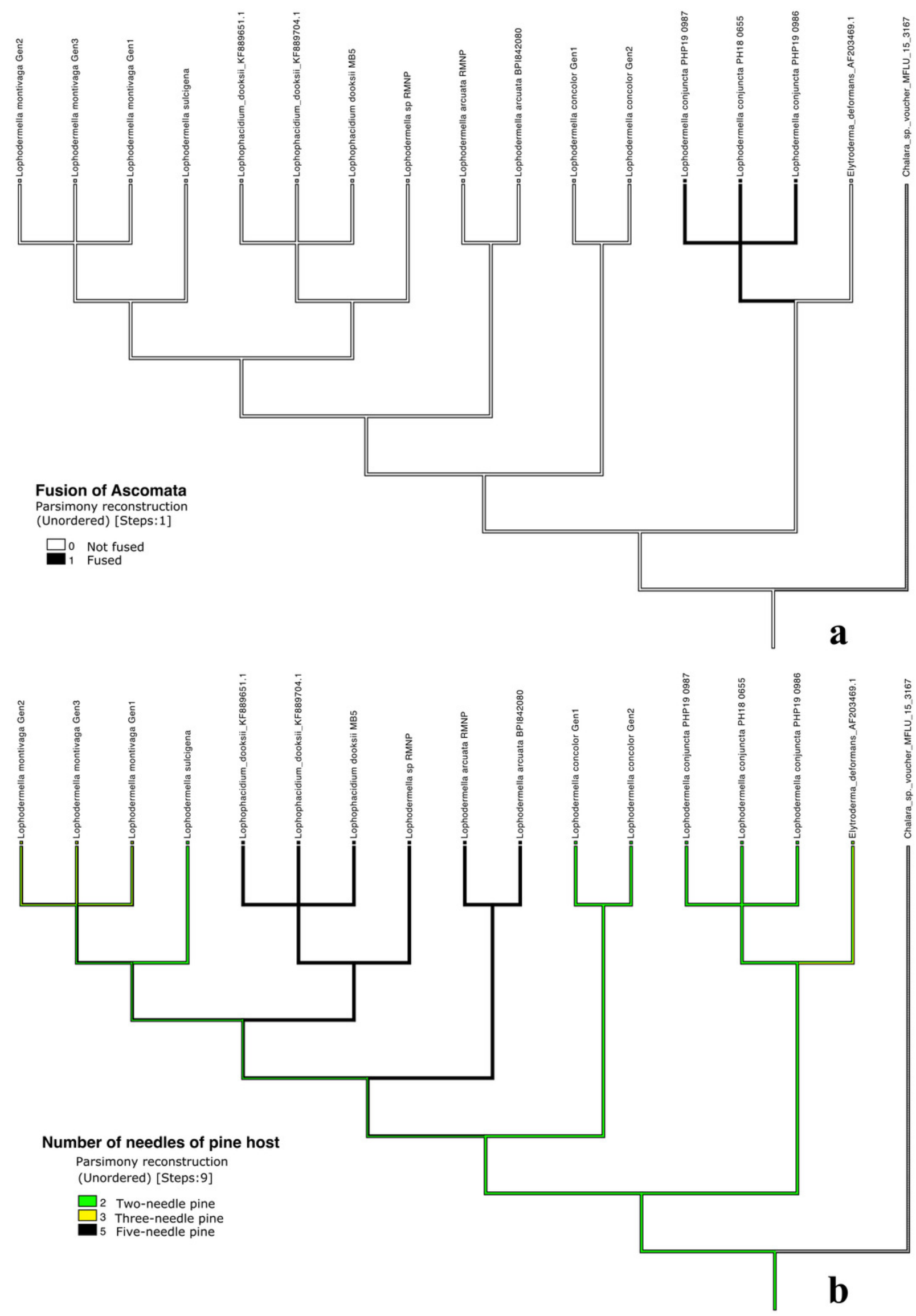


\section{Table $\mathbf{1}$ (on next page)}

Collection information, GenBank accession and genotype numbers for each Lophodermella species and Lophophacidium dooksii for the three loci

Collection information, GenBank accession and genotype numbers for each Lophodermella species and Lophophacidium dooksii for the three loci, namely: internal transcribed spacer region 1, 5.8S ribosomal RNA and internal transcribed spacer region 2 (ITS), large ribosomal subunit (LSU) and translation elongation factor (TEF1-a). 
Table 1. Collection information, GenBank accession and genotype numbers for each Lophodermella species and Lophophacidium dooksii for the three loci, namely: internal transcribed spacer region 1, 5.8S ribosomal RNA and internal transcribed spacer region 2

3 (ITS), large ribosomal subunit (LSU) and translation elongation factor (TEF1- $\alpha$ ).

\begin{tabular}{|c|c|c|c|c|c|c|c|}
\hline \multirow[t]{2}{*}{ Sample ID } & \multirow{2}{*}{ Location } & \multirow{2}{*}{ Host } & \multirow{2}{*}{$\begin{array}{c}\text { Collection } \\
\text { Date }\end{array}$} & \multirow[t]{2}{*}{ Collectors } & \multicolumn{3}{|c|}{$\begin{array}{c}\text { GenBank Accession Number; } \\
\text { (Genotype) }\end{array}$} \\
\hline & & & & & ITS & LSU & TEF1- $\alpha$ \\
\hline \multicolumn{8}{|c|}{ Lophodermella concolor (Dearn.) Darker } \\
\hline CS6C & $\begin{array}{l}\text { CS, GNF, CO, } \\
\text { USA }\end{array}$ & Pinus contorta & 12 June 2018 & $\begin{array}{l}\text { JE Stewart, JP Ata, } \\
\text { KS Burns, SB } \\
\text { Marchetti, JJ Worrall }\end{array}$ & $\begin{array}{l}\text { MN937619; } \\
\text { (1) }\end{array}$ & $\begin{array}{l}\text { MN937581; } \\
\text { (1) }\end{array}$ & $\begin{array}{l}\text { MN937651; } \\
\text { (1) }\end{array}$ \\
\hline CS9C & $\begin{array}{l}\text { CS, GNF, CO, } \\
\text { USA }\end{array}$ & P. contorta & 12 June 2018 & $"$ & $\begin{array}{l}\text { MN937612; } \\
\text { (1) }\end{array}$ & $\begin{array}{l}\text { MN937579; } \\
(1)\end{array}$ & $\begin{array}{l}\text { MN937650; } \\
\text { (1) }\end{array}$ \\
\hline FS6C & $\begin{array}{l}\text { FS, GNF, CO, } \\
\text { USA }\end{array}$ & P. contorta & 12 June 2018 & " & $\begin{array}{l}\text { MN937618; } \\
\text { (1) }\end{array}$ & $\begin{array}{l}\text { MN937582; } \\
(1)\end{array}$ & $\begin{array}{l}\text { MN937647; } \\
\text { (1) }\end{array}$ \\
\hline FS8C & $\begin{array}{l}\text { FS, GNF, CO, } \\
\text { USA }\end{array}$ & P. contorta & 12 June 2018 & " & $\begin{array}{l}\text { MN937610; } \\
(2)\end{array}$ & $\begin{array}{l}\text { MN937580; } \\
(1)\end{array}$ & $\begin{array}{l}\text { MN937653; } \\
\text { (1) }\end{array}$ \\
\hline LP7C & $\begin{array}{l}\text { LP, GNF, CO, } \\
\text { USA }\end{array}$ & P. contorta & 12 June 2018 & $"$ & $\begin{array}{l}\text { MN937621; } \\
\text { (1) }\end{array}$ & $\begin{array}{l}\text { MN937588; } \\
(3)\end{array}$ & $\begin{array}{l}\text { MN937654; } \\
\text { (1) }\end{array}$ \\
\hline LV7C & $\begin{array}{l}\text { LV, GNF, CO, } \\
\text { USA }\end{array}$ & P. contorta & 14 June 2018 & $"$ & $\begin{array}{l}\text { MN937620; } \\
\text { (1) }\end{array}$ & $\begin{array}{l}\text { MN937575; } \\
\text { (1) }\end{array}$ & $\begin{array}{l}\text { MN937657; } \\
\text { (1) }\end{array}$ \\
\hline LV8C & $\begin{array}{l}\text { LV, GNF, CO, } \\
\text { USA }\end{array}$ & P. contorta & 12 June 2018 & " & $\begin{array}{l}\text { MN937615; } \\
\text { (1) }\end{array}$ & $\begin{array}{l}\text { MN937576; } \\
(2)\end{array}$ & $\begin{array}{l}\text { MN937655; } \\
\text { (1) }\end{array}$ \\
\hline PT2C & $\begin{array}{l}\text { PT, GNF, CO, } \\
\text { USA }\end{array}$ & P. contorta & 14 June 2018 & " & $\begin{array}{l}\text { MN937616; } \\
\text { (1) }\end{array}$ & $\begin{array}{l}\text { MN937577; } \\
(1)\end{array}$ & $\begin{array}{l}\text { MN937646; } \\
\text { (1) }\end{array}$ \\
\hline PT3C & $\begin{array}{l}\text { PT, GNF, CO, } \\
\text { USA }\end{array}$ & P. contorta & 14 June 2018 & $"$ & $\begin{array}{l}\text { MN937614; } \\
\text { (1) }\end{array}$ & $\begin{array}{l}\text { MN937583; } \\
\text { (1) }\end{array}$ & $\begin{array}{l}\text { MN937652; } \\
\text { (1) }\end{array}$ \\
\hline SR3C & $\begin{array}{l}\text { SR, GNF, CO, } \\
\text { USA }\end{array}$ & P. contorta & 13 June 2018 & $"$ & $\begin{array}{l}\text { MN937617; } \\
\text { (1) }\end{array}$ & $\begin{array}{l}\text { MN937578; } \\
\text { (1) }\end{array}$ & $\begin{array}{l}\text { MN937649; } \\
\text { (1) }\end{array}$ \\
\hline SR6C & $\begin{array}{l}\text { SR, GNF, CO, } \\
\text { USA }\end{array}$ & P. contorta & 13 June 2018 & $"$ & $\begin{array}{l}\text { MN937613; } \\
\text { (1) }\end{array}$ & $\begin{array}{l}\text { MN937584; } \\
\text { (1) }\end{array}$ & $\begin{array}{l}\text { MN937648; } \\
\text { (1) }\end{array}$ \\
\hline OJ11C & $\begin{array}{l}\text { OJ, GNF, CO, } \\
\text { USA }\end{array}$ & P. contorta & 13 June 2018 & " & $\begin{array}{l}\text { MN937611; } \\
\text { (1) }\end{array}$ & $\begin{array}{l}\text { MN937574; } \\
(1)\end{array}$ & $\begin{array}{l}\text { MN937656; } \\
\text { (1) }\end{array}$ \\
\hline & & & Lophoderme & ontvaga & & & \\
\hline
\end{tabular}




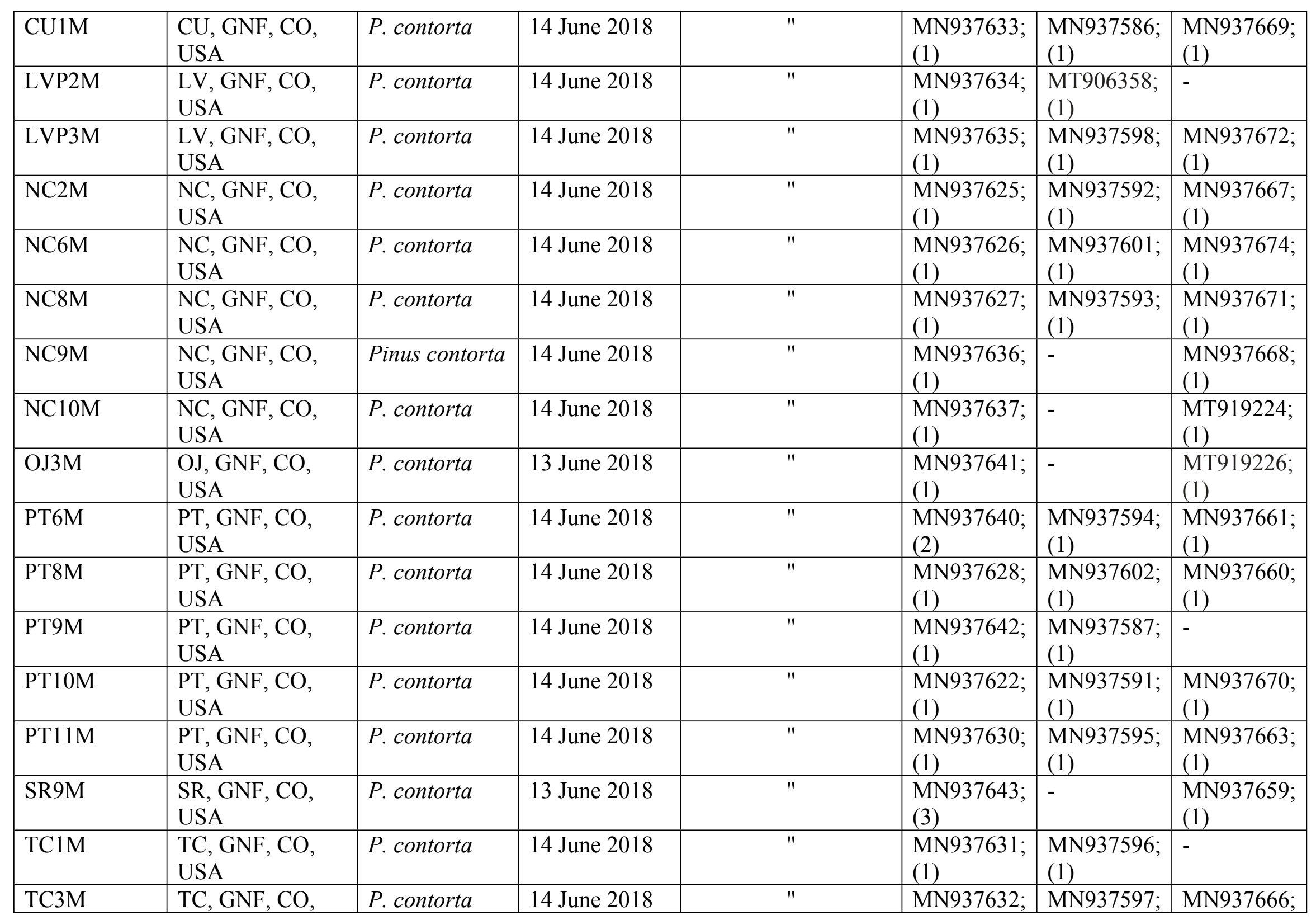




\begin{tabular}{|c|c|c|c|c|c|c|c|}
\hline & USA & & & & $(1)$ & $(1)$ & $(1)$ \\
\hline TC9M & $\begin{array}{l}\text { TC, GNF, CO, } \\
\text { USA }\end{array}$ & P. contorta & 14 June 2018 & $"$ & $\begin{array}{l}\text { MN937629; } \\
\text { (1) }\end{array}$ & $\begin{array}{l}\text { MN937599; } \\
\text { (1) }\end{array}$ & $\begin{array}{l}\text { MN937673; } \\
\text { (1) }\end{array}$ \\
\hline TL8M & $\begin{array}{l}\text { TL, GNF, CO, } \\
\text { USA }\end{array}$ & P. contorta & $\begin{array}{l}21 \text { August } \\
2018\end{array}$ & SB Marchetti & $\begin{array}{l}\text { MN937638; } \\
\text { (1) }\end{array}$ & $\begin{array}{l}\text { MN937600; } \\
\text { (1) }\end{array}$ & $\begin{array}{l}\text { MN937662; } \\
\text { (1) }\end{array}$ \\
\hline TL9M & $\begin{array}{l}\text { TL, GNF, CO, } \\
\text { USA }\end{array}$ & P. contorta & $\begin{array}{l}21 \text { August } \\
2018\end{array}$ & SB Marchetti & $\begin{array}{l}\text { MN937639; } \\
\text { (2) }\end{array}$ & - & $\begin{array}{l}\text { MT919225; } \\
\text { (1) }\end{array}$ \\
\hline \multicolumn{8}{|c|}{ Lophodermella arcuata (Darker) Darker } \\
\hline RMNP_LU1 & RMNP, CO, USA & P. flexilis & 24 July 2019 & KS Burns & $\begin{array}{l}\text { MN937644; } \\
\text { (1) }\end{array}$ & $\begin{array}{l}\text { MN937585; } \\
\text { (1) }\end{array}$ & $\begin{array}{l}\text { MN937658; } \\
\text { (1) }\end{array}$ \\
\hline RMNP_LU16 & RMNP, CO, USA & P. flexilis & 24 July 2019 & KS Burns & $\begin{array}{l}\text { MT906333; } \\
\text { (1) }\end{array}$ & $\begin{array}{l}\text { MT906359; } \\
(1)\end{array}$ & $\begin{array}{l}\text { MT919227; } \\
\text { (2) }\end{array}$ \\
\hline \multicolumn{8}{|c|}{ Lophodermella sulcigena (Rostr.) Höhn. } \\
\hline PH18_0656 & $\begin{array}{l}\text { Canton Ticino, } \\
\text { Passo del } \\
\text { Lucomagno, SW }\end{array}$ & Pinus mugo & 10 July 2018 & G Moretti & MN937624 & MN937604 & MN937675 \\
\hline \multicolumn{8}{|c|}{ Lophodermella conjuncta (Darker) Darker } \\
\hline PH18_0655 & $\begin{array}{l}\text { Canton Grisons, } \\
\text { Lenzerheide, SW }\end{array}$ & P. mugo & 18 April 2018 & M Vanoni & $\begin{array}{l}\text { MN937607; } \\
\text { (1) }\end{array}$ & $\begin{array}{l}\text { MN937605; } \\
(1)\end{array}$ & $\begin{array}{l}\text { MN937677; } \\
\text { (1) }\end{array}$ \\
\hline PHP19_0986 & $\begin{array}{l}\text { Canton Bern, } \\
\text { Kandersteg, } \\
\text { Oeschi-Forest, } \\
\text { CH }\end{array}$ & P. mugo & 18 June 2018 & J Meyer, L Beenken & $\begin{array}{l}\text { MN937609; } \\
\text { (2) }\end{array}$ & $\begin{array}{l}\text { MN937606; } \\
\text { (1) }\end{array}$ & $\begin{array}{l}\text { MN937676; } \\
\text { (1) }\end{array}$ \\
\hline PHP19_0987 & $\begin{array}{l}\text { Tyrol, Scharnitz, } \\
\text { Karwendel } \\
\text { Valley, AT }\end{array}$ & P. mugo & 11 June 2018 & T Cech, L. Beenken & $\begin{array}{l}\text { MN937608; } \\
\text { (3) }\end{array}$ & $\begin{array}{l}\text { MN937603; } \\
\text { (1) }\end{array}$ & $\begin{array}{l}\text { MN937678; } \\
\text { (1) }\end{array}$ \\
\hline
\end{tabular}


Location: CS - Cold Springs Campground, CU - Cumberland, FS - Fisherman Trail, LP - Lodgepole Campground, LV - Lakeview Campground, NC - North Cumberland, OJ - Oh Be Joyful, PT - Pitkin, SR - Slate River, TC - Tincup, TL - Taylor Park, GNF - Gunnison National Forest, RMNP - Rocky Mountain National Park, CO - Colorado, ME - Maine,

USA - United States of America, CH - Switzerland, AT - Austria 


\section{Table 2 (on next page)}

Characteristics of Lophodermella species and Lophophacidium dooksii based on published descriptions

Characteristics of Lophodermella species and Lophophacidium dooksii based on published descriptions 
1 Table 2. Characteristics of Lophodermella species and Lophophacidium dooksii based on published descriptions

\begin{tabular}{|c|c|c|c|c|c|}
\hline Features & $\begin{array}{c}\text { Lophodermella concolor } \\
\text { (Dearn.) Darker }\end{array}$ & $\begin{array}{c}\text { Lophodermella montivaga } \\
\text { Petrak }\end{array}$ & $\begin{array}{c}\text { Lophodermella arcuata } \\
\text { (Darker) Darker }\end{array}$ & $\begin{array}{c}\text { Lophodermella sulcigena } \\
\text { (Rostr.) Höhn }\end{array}$ & $\begin{array}{l}\text { Lophodermella conjuncta } \\
\text { (Darker) Darker }\end{array}$ \\
\hline \multicolumn{6}{|c|}{ Ascomata (hysterothecia) } \\
\hline Size $(\mathrm{mm})$ & $0.4-0.8 \times 0.28-0.44$ & $0.75-8 \times 0.28-0.4$ & $0.38-3.13 \times 0.25-0.45$ & $2-20 \times 0.30-0.45$ & $0.50-4.0 \times 0.20-0.30$ \\
\hline Depth $(\mu \mathrm{m})$ & $200-280$ & $220-250$ & $210-260$ & $200-250$ & $140-180$ \\
\hline Opening & longitudinal split along stomata & longitudinal split & $\begin{array}{c}\text { Longitudinal split along } \\
\text { stomata }\end{array}$ & longitudinal split & longitudinal split \\
\hline \multicolumn{6}{|l|}{ Paraphyses } \\
\hline Size $(\mu \mathrm{m})$ & About as long as the asci & Up to $150 \times c a 1$ & $120-135 \times 0.5-1$ & $100-120 \times 1$ & $135-150 \times 1.0-2.0$ \\
\hline $\begin{array}{l}\text { Gelatinous sheath/ } \\
\text { Mucous coat }\end{array}$ & Present & Present & Present & Present & Absent \\
\hline Septation & Present & Present & Inconspicuous & Present & Present \\
\hline \multicolumn{6}{|l|}{$A s c i$} \\
\hline Size $(\mu \mathrm{m})$ & $120-225 \times 15-17$ & $120-160 \times 12-15$ & $110-160 \times 14-20$ & $110-140 \times 13-15$ & $(100) 110-160 \times 15-16$ \\
\hline $\begin{array}{l}\text { Opening } \\
\text { mechanism }\end{array}$ & $\begin{array}{l}\text { No obvious pre-formed apical } \\
\text { apparatus (small apical hole or } \\
\text { split after spores are released) }\end{array}$ & $\begin{array}{l}\text { No obvious pre-formed } \\
\text { apical apparatus (small } \\
\text { apical hole or split after } \\
\text { spores are released) } \\
\end{array}$ & $\begin{array}{l}\text { No obvious pre-formed } \\
\text { opening mechanism (small } \\
\text { apical hole or split after } \\
\text { spores are released) }\end{array}$ & $\begin{array}{c}\text { No obvious pre-formed apical } \\
\text { apparatus }\end{array}$ & $\begin{array}{c}\text { No obvious pre-formed apical } \\
\text { apparatus }\end{array}$ \\
\hline Number of spores & 8 & 8 & 8 & $4-8$ & 8 \\
\hline \multicolumn{6}{|l|}{ Ascospore } \\
\hline Size $(\mu \mathrm{m})$ & $45-60 \times(4) 6-8$ & $40-50 \times 3-4$ & $40-50-(95) \times 4-6$ & $27-40(65) \times 4-5(6)$ & $(65) 75-90(100) \times 2.5-3.5$ \\
\hline $\begin{array}{l}\text { Mucilaginous/ } \\
\text { gelatinous sheath }\end{array}$ & Present & Present & Present & Present & Present \\
\hline $\begin{array}{l}\text { Hosts (number of } \\
\text { needles) }\end{array}$ & $\begin{array}{c}\text { Pinus banksiana (2), P. contorta } \\
\text { (2), P. contorta var. murrayana } \\
\text { (2), P. sylvestris }(2)\end{array}$ & $\begin{array}{l}\text { Pinus attenuata (3), } P . \\
\text { contorta }(2), P . \text { sylvestris } \\
(2), P . \text { ponderosa }(3), P . \\
\text { radiata }(3), P . \text { flexilis }(5), \\
P . \text { monticola }(5) \\
\end{array}$ & $\begin{array}{l}\text { Pinus albicaulis (5), } P . \\
\text { flexilis (5), P. lambertiana } \\
\text { (5), P. monticola (5) }\end{array}$ & $\begin{array}{l}\text { Pinus sylvestris (2), P. mugo } \\
\text { (2), P. nigra var. maritima (2) }\end{array}$ & $\begin{array}{l}\text { Pinus mugo (2), P. nigra var. } \\
\text { Maritima (2), P. sylvestris (2). }\end{array}$ \\
\hline Distribution & Western USA, Canada & Western USA & Western USA & Europe & Europe \\
\hline Conidiomata & Not observed & Not observed & Not observed & Unknown & Unknown \\
\hline References & $\begin{array}{c}\text { Darker 1932, Millar 1984, Minter } \\
\text { and Millar 1993b, Funk 1985, } \\
\text { Worrall et al. } 2012\end{array}$ & $\begin{array}{l}\text { Darker 1932, Millar 1984, } \\
\text { Minter and Millar 1993c, } \\
\text { Worrall et al. } 2012\end{array}$ & $\begin{array}{l}\text { Darker 1932, Minter and } \\
\text { Millar 1993a }\end{array}$ & $\begin{array}{l}\text { Darker 1932, Millar 1984, } \\
\text { Millar and Minter 1978, } \\
\text { Beenken } 2019\end{array}$ & $\begin{array}{c}\text { Darker 1932, Millar 1984, Millar } \\
\text { and Minter 1966, } \\
\text { Beenken } 2019\end{array}$ \\
\hline
\end{tabular}


13 Table 2. Characteristics of Lophodermella species and Lophophacidium dooksii based on published descriptions (cont'd)

\begin{tabular}{|c|c|c|c|c|c|}
\hline Features & $\begin{array}{l}\text { Lophodermella cerina } \\
\text { (Darker) Darker }\end{array}$ & $\begin{array}{l}\text { Lophodermella maureri } \\
\text { Minter and Cibrián }\end{array}$ & $\begin{array}{c}\text { Lophodermella morbida } \\
\text { Staley and Bynum }\end{array}$ & $\begin{array}{c}\text { Lopodermella orientalis } \\
\text { Minter and Ivory }\end{array}$ & $\begin{array}{l}\text { Lophophacidium dooksii } \\
\text { Corlett \& Shoemaker }\end{array}$ \\
\hline \multicolumn{6}{|c|}{ Ascomata (hysterothecia) } \\
\hline Size $(\mathrm{mm})$ & $0.6-2.75 \times 0.3-0.63$ & $300-2500 \times 250-550$ & $1-6(22)$ & $0.5-2 \times 0.4-0.8$ & $(4.5-) 13-22 \times 0.28-0.4$ \\
\hline Depth $(\mu \mathrm{m})$ & ca 280 & -- & $350-370$ & -- & $180-280$ \\
\hline Opening & $\begin{array}{c}\text { longitudinal split along } \\
\text { stomata }\end{array}$ & Longitudinal split & -- & $\begin{array}{c}\text { longitudinal split along } \\
\text { stomata }\end{array}$ & Vertical row of cells \\
\hline \multicolumn{6}{|l|}{ Paraphyses } \\
\hline Size $(\mu \mathrm{m})$ & $180-200 \times 1-3$ & $2.5-3.5$ (width) & $120-140 \times 2-3.5$ & 2-3 (width) & $(80-) 90-120 \times 1.5-2.0$ \\
\hline $\begin{array}{l}\text { Gelatinous } \\
\text { sheath/Mucous } \\
\text { coat }\end{array}$ & Present (inconspicuous) & Present & -- & Present & Present \\
\hline Septation & Present & Present & Present & Present & Present \\
\hline \multicolumn{6}{|l|}{ Asci } \\
\hline Size $(\mu \mathrm{m})$ & $160-225 \times 17-21$ & $55-80 \times 8-13$ & $95-162$ & $110-150 \times 14-18$ & $\begin{array}{c}(70-) 85-110(-120) \times 14-18(- \\
20)\end{array}$ \\
\hline $\begin{array}{l}\text { Opening } \\
\text { mechanism }\end{array}$ & $\begin{array}{l}\text { No obvious pre-formed } \\
\text { apical apparatus (small } \\
\text { apical hole or split after } \\
\text { spores are released) }\end{array}$ & Opening by a large apical hole & -- & $\begin{array}{c}\text { No obvious pre-formed apical } \\
\text { apparatus (small apical hole } \\
\text { or split after spores are } \\
\text { released) }\end{array}$ & Unitunicate \\
\hline $\begin{array}{l}\text { Number of } \\
\text { spores }\end{array}$ & 8 & 8 & 8 & 8 & 8 \\
\hline \multicolumn{6}{|l|}{ Ascospore } \\
\hline Size $(\mu \mathrm{m})$ & $68-78 \times 3-3.5$ & $30-50 \times 2.5-3.5$ & $23-53 \times 2.5-3.5$ & $30-65 \times 2.5-3.5$ & $22-32 \times 6-7.5$ \\
\hline $\begin{array}{l}\text { Mucilaginous/gel } \\
\text { atinous sheath }\end{array}$ & Present & Present & Present & Present & Lacking \\
\hline $\begin{array}{l}\text { Hosts (number of } \\
\text { needles) }\end{array}$ & $\begin{array}{l}\text { Pinus contorta (2), } P . \\
\text { elliottii var. elliottii (3), } P \text {. } \\
\text { ponderosa (3), P. taeda (3), } \\
P . \text { sylvestris (2) }\end{array}$ & Pinus ayacahuite (5) & $\begin{array}{c}\text { Pinus ponderosa }(3), P \text {. } \\
\text { attenuata }(3)\end{array}$ & $\begin{array}{c}\text { Pinus kesiya }(3, \text { sometimes } 2 \\
\text { or } 4)\end{array}$ & Pinus strobus (5) \\
\hline Distribution & Western USA & Mexico & Western USA & Asia & Canada, USA \\
\hline Conidiomata & Not observed (present in $P$. & Not observed & Present & Only fresh collected & Not reported \\
\hline
\end{tabular}




\section{PeerJ}

\begin{tabular}{|l|c|c|c|c|}
\hline & contorta $)$ & & specimens \\
\hline References & $\begin{array}{c}\text { Darker 1932, Millar 1984, } \\
\text { Minter and Millar 1993d }\end{array}$ & Minter 1988b & Staley and Bynum 1972 & Minter 1993 \\
\hline
\end{tabular}

14 


\section{Table 3(on next page)}

Character and character states used for phylogenetic reconstructions of Lophodermella species.

Character and character states used for phylogenetic reconstructions of Lophodermella species. A. Characters to assess genus delineation B. Characters to assess species delineation 
1 Table 3. Character and character states used for phylogenetic reconstructions of Lophodermella species.

A. Characters to assess genus delineation

\begin{tabular}{|l|l|l|}
\hline No. & Character & Character States \\
\hline 1 & Ascomata: Shape & $\begin{array}{l}\text { 0 non-linear or -elliptical, 1 mostly linear, } \\
\text { nervisequious, dark brown to black, 2 mostly } \\
\text { elliptical to elongate, concolorous to black }\end{array}$ \\
\hline 2 & $\begin{array}{l}\text { Ascomata: Position on substrate/host } \\
\text { tissue (median transverse section) }\end{array}$ & $\begin{array}{l}\text { 0 external/superficial, 1 subcuticular, } 2 \\
\text { intraepidermal, 3 subepidermal, 4 subhypodermal }\end{array}$ \\
\hline 3 & Asci: Shape & $\begin{array}{l}\text { 0 more or less broadly saccate to clavate, 1 narrowly } \\
\text { clavate or cylindrical }\end{array}$ \\
\hline & & $\begin{array}{l}\text { 0 acicular, 1 filiform, 2 clavate, 3 cylindrical, } 4 \text { fusiform } \\
\text { to oval, 5 rod-shaped, 6 double spindle-shaped, } 7 \\
\text { ellipsoid to fusiod }\end{array}$ \\
\hline 5 & Ascospores: Shape & 0 non-pine, 1 pine \\
\hline
\end{tabular}

B. Characters to assess species delineation

\begin{tabular}{|l|l|l|}
\hline 1 & Ascomata: length & 0 hysterothecia $\geq 1 \mathrm{~mm}, 1$ hysterothecia short \\
\hline 2 & Ascomata: color & 0 brown, 1 concolorous \\
\hline 3 & Ascomata: fusion & 0 not fused, 1 fused \\
\hline & & 0 short $(23-60 \mu \mathrm{m})$ clavate, 1 elongate clavate $(68-90 \mu \mathrm{m})$, \\
& Ascospores: shape, size & 4 four-spored, 8 eight-spored \\
\hline 5 & Asci: number of spores & 2 two-needle pine, 3 three-needle pine, 5 five-needle pine \\
\hline 6 & Host: number of pine needles &
\end{tabular}

